have gone on to consider what must be inferred if this assump. tion is not true; observing that "awliwardly enough, its truth and its untruth are alike fatal to the conclusions of those who argue after the manner of Humboldt. Note the alternatives":"On the one band, what follows from the mitruth of the assumption? If apparent largeness of stars is not due to comparative nearness, and their successively smaller sizes to their greater and greater degrees of remoteness, what becomes of the inferences respecting the dimensions of our sidereal system and the distances of the nebula? If, as has lately been shown, the almost invisible star, 6I Cygni, has a greater parallax than a Cygni, though, according to an estimate based on Sir W. Herschel's assumption, it should be about twelve times more distant-if, as it turns out, there exist telescopic stars which are nearer to us than Sirius, of what worth is the conclusion that the nebulx are very remote, because their component luminous masses are made visible only by high telescopic powers?. . On the other hand, what follows if the truth of the assumption be granted? The arguments used to justify this assumption in the case of the stars, equally justify it in the case of the nebule. It cannot be contended that, on the average, the apparent sizes of the stars indicate their distances, withont its being admitted that, on the average, the approrent sizes of the nebula indicate their distances-that, generally speaking, the larger are the nearer, and the smaller are the more distant. Mark, now, the necessary inference respecting their resolvability. The largest or nearest nebule will be most easily resolved into stars; the successively smaller will be succcssively more difficult of resolution; and the irresolvable ones will be the smaller ones. This, however, is exactly the reverse of the fact. The largest nebulæ are either wholly irresolvable, or but partially resolvable under the highest telescopic powers; while a great proportion of quite small nebule are easily resolv able by far less powerful telescopes."

At the time when these passages were written, spectrumanalysis had not yielded the conclusive proof which we now possess, that many nebula consist of matier in a diffused form. But quite apart from the evidence yielded by spectrum-analysis, it seems to me that the incongrutities and contradictions which may be evolved from the hypothesis that nebula are remote sidereal systems, amply suffice to show that hypothesis to be untenable.

37. Queen's Gardens, Jan. 3r Herbert Spencer

\section{Kant's View of Space}

IN answer to my invitation, $\mathrm{Mr}$. Lewes now "freely admits that Kant nowhere speaks of Space and Time as "Forms of Thought," "but still contends that "Kant would not have dis. claimed such language, as misrepresenting his meaning.' As well might he argue that although Euclid never uses the word epipedon (our English word plane or plainl, to signify a curved surface $(\epsilon \pi / \phi a \nu \in i \alpha)$, he would not have remonstrated against the use of the term cylindrical epipedon or conical epipedon, to denote the surface of a cylinder or cone, in a professed exposition or criticism of his Elements of Geometry, because in common life we speak of rough or undulating plains, or because a plane admits of being bent into the shape of a cylindrical or conical surface. I think the ladies who are getting up their Planes and Solids at St. George's Hall wonld be of a different opinion from Mr. Lewes in this matter, and with good reason on their side.

Mr. Lewes, reiterating a statement containesl in his previous letter, goes out of his way to affrm that he "uniformly speaks of Space and Time as forms of Intuition in his pages of exposition" of Kant's doctrine in his "History of Philosophy." Were the fact so, it would not in any materinl clegree excuse the inaccuracy of subsequently styling them "forms of Thought;" and, moreover, the real point at issue is not Mr. Lewes's general accuracy or inaccuracy, but whether a mode of speech which he, along with others, employs, is right in itself and onght to be persisted in.

However, as Mr. Lewes has thought fit to put in a sort of plea in mitigation of former wrong-cloing, I have taken the trouble of looking through his exposition and criticism of Kant in his History (ed. 1867), and in no single instance have I come upon the phrase forms of intuition applied to Space and Time, either in the one or the other; although he states he has uniformly spoken of them as such in the former. I have marked the word intuitions as occurring once, and forms of sertsibility several times, but forms of intuition never. If form of sensibility is as good to use as form of intuition, form of understanding ought to be as good as form of thought; but Mr. Lewes owns that the former is indefensible, whilst he avers that the latter is correct. If $\mathrm{Mr}$. Lewes has ever called Space and Time fornts of intuition in the Ifistory, it will be easy for him to set me right by quoting the passage where the phrase occurs, although that circumstance would not in any degree better his own position, and still less excuse the assertion of his uniform use of the term.

If Mr. Lewes cannot quote correctly from his own writings, it will surprise nobody that he misquotes the language of an opponent. He repeats, "Intuition without thought is mere sensuous impression," and adds, "Mr. Sylvester demurs to this," "My words are" (NATURE, Jan, 13, 1870): "To such a misuse of the word energy it would be little to the point to urge that force without energy is mere potential tendency. It is just as little to the point in the matter at issue for Mx. Lewes to inform the readers of NATURE that intuition without thousht is mere sensuous impression." So that, according to Mr. Lewes, to say that a proposition is little to the point is demurring to its tratth.

I should not hesitate to say if some amiable youth wished to entertain his partner in a quadrille with agreeable conversation, that it would be little to the point, according to the German proverb, to regale her with such information as how

And tall the towers of Strasburg's fane,"

but should be surprised to have it imputed to me on that account that I demmxed to the proposition of the length of the days in summer, or the height of Strasburg's towers.

In another passage, Mr. Lewes gives me credit for "saying correctly that Intuition and Thought are not convertible terms"a platitude I never dreamed of giving utterance to; but that I am "incorrect in assuming that they differ as potential and actual "-words which, or the like of which, in any sort or sense, never flowed from my pen. Surely this is not fair controversy, to misquote the words and allegations of an opponent. It seems to me too much like fighting with poisoned weapons. I decline to continue the contest on such terms; and, passing over Mr. Lewes's very odd statement about species and gennis with reference to Intuition and Thonght, shall conclude with expressing my surprise at his and Mr. G. C. Robertson's confident assumption that Kant uses in the title of his book pure reason in a far wider. sense than in the body of his work, simply because to arrive at the Pure Reason he has to go through the Critick of the Sensibility and of the Understanding. If in a history of the Reign of Queen Victoria the author should find it expedient to go back to the times of the Norman and Saxon conquests, would it be right to infer therefrom that he used in his title-page the name Victoria in a generalised sense, to include not only her most Gracious Majesty, but also the Tanner's daughter and Princess Rowena?

Perhaps by this time many of the Naturalistic readers of the journal who regard the human intelligence as forming no part of the scheme of Nature, wish Space at the bottom of the sea; but the more the snbject is canvassed, and the greater the number of English authorities brought forward to back up Mr. Lewes in wresting the words of Kant from their proper scientific signification, the higher meed of praise seems to me to accrue to Dr. Ingleby for stemming the tide of depravation, and banishing, as I feel confident this discussion will have the effect of doing, from the realm of English would-be philosophy, such a loose and incautious way of talking as that of giving to Space and Time the designation which the Master has appropriated to the categories of his system, and to them alone.

J. J. Sylvester

P.S.-I should be doing injustice to the very sincere sentiments of respect I entertain for Mr. Lewes's varied and brilliant attainments (which constitute him a kind of link between the material and spiritual sides of Nature), and of gratitude for the pleasure the perusal of his "History of Philosophy" has afforded me, were I to part company with him without disclaiming all acrimony of feeling, if perchance any too strident tones should have seemed to mingle with my enforced reply. In naming him in the original offending footnote (the fountain of these tears), my purpose was simply to emphasise the necessity of protesting against what seemed to me an unsound form of words, dpropos of Kant, which went on receiving countenance from sucl and so eminent writers as himself and the others named; and I should be false to my own instincts did $I$ not at heart admire the courageous spirit with which, almost maided and alone (like a good knight of old), he has done his best to defend his position and maintain his ground against all oppugners. 